\title{
How Can Companies Decrease Salesperson Turnover Intention? The Corporate Social Responsibility Intervention
}

\author{
Sandra Castro-González ${ }^{1, *(\mathbb{D})}$, Belén Bande ${ }^{1}$ and Guadalupe Vila-Vázquez ${ }^{2}$ (D) \\ 1 Department of Business Organization and Commercialization, Universidade de Santiago de Compostela, \\ 27002 Lugo, Spain; belen.bande@usc.es \\ 2 Department of Business Organization and Commercialization, Universidade de Santiago de Compostela, \\ 15782 Santiago de Compostela, Spain; guadalupe.vila@usc.es \\ * Correspondence: sandra.castro@usc.es
}

Citation: Castro-González, S.; Bande,

B.; Vila-Vázquez, G. How Can

Companies Decrease Salesperson Turnover Intention? The Corporate Social Responsibility Intervention. Sustainability 2021, 13, 750. https:// doi.org/10.3390/su13020750

Received: 26 December 2020 Accepted: 12 January 2021 Published: 14 January 2021

Publisher's Note: MDPI stays neutral with regard to jurisdictional clai$\mathrm{ms}$ in published maps and institutional affiliations.

Copyright: (C) 2021 by the authors. Licensee MDPI, Basel, Switzerland. This article is an open access article distributed under the terms and conditions of the Creative Commons Attribution (CC BY) license (https:// creativecommons.org/licenses/by/ $4.0 /)$.

\begin{abstract}
Salespeople turnover is a key issue that can threaten a company's survival, either by reducing its income or increasing its expenses. The purpose of this study is to analyze the impact of corporate social responsibility (CSR) practices on the salespeople turnover. Drawing from social network theory, this research suggests that the perception of CSR practices influences salespeople turnover through their impact on the perception of the company's reputation and the organizational pride that sellers experience. Additionally, the moderating role of interpersonal justice in the CSRorganizational pride relationship is analyzed. The data was collected from a sample of 176 salespeople and their supervisors from 96 companies. Structural equation modeling was used to analyze the psychometric properties of the measurement scales and to test the proposed direct hypotheses, and conditional process analysis was used to test the proposed mediation hypothesis. The results indicate that CSR is negatively related to salesperson turnover via the perceived salespeople's organizational pride and organizational reputation. Furthermore, this study's findings confirm the importance of a salesperson's interpersonal justice for these relationships. This study contributes to the existing sales and management literature by enhancing our understanding of how to reduce salespeople turnover intention. Specifically, it underlines the role of CSR practices in reducing those intentions.
\end{abstract}

Keywords: sales; CSR; corporate reputation; organizational pride; turnover intention; interpersonal justice

\section{Introduction}

Corporate social responsibility (CSR) defined as "context-specific organizational actions and policies that take into account stakeholders' expectations and the triple bottom line of economic, social, and environmental performance" ([1] p. 855), has been recognized as a strategic factor for the achievement of the firms' sustainable development [2-5]. In fact, CSR allows firms to improve not only their profitability but also their social impact [4].

Despite growing interest in CSR studies, most research in this area has focused on the macro level $[4,6]$. Consequently, recent work in CSR literature e.g., [7,8] highlight the need for future studies to understand incumbent employee reactions to their perceptions of CSR.

From a marketing point of view, organizations can implement CSR activities to influence consumers' or salespeople's attitudes and behaviors. Nevertheless, there is a significant lack of evidence on how CSR affects salespeople's attitudes and behaviors, with only a few studies analyzing such relationships e.g., [9,10]. In recent years, the CSR and human resources literature has begun to analyze the micro-level effects of CSR, but it excludes salespeople.

One of the ways in which CSR promotes the sustainability of organizations is by promoting employee retention [4,11]. Salesperson turnover intention is a thought-provoking problem which companies frequently have to deal with [12]. In fact, sales turnover entails 
significant costs both from a customer perspective and in terms of human resource management [13]. On the one hand, a stable sales force plays a very significant role in the process of acquisition and consumer engagement [14]. On the other hand, salespeople turnover involves significant recruitment and training costs [12,15]. Nevertheless, according to Forbes, salespeople turnover rates considering both voluntary and involuntary turnover is between $20 \%$ and $34 \%$ [16].

High frontline workers turnover rate can be attributed to ethical dilemmas with they face on a daily basis [17], placing them in a very noticeable role for ethical behavior [18]. Furthermore, not surprisingly, current selling context and conditions have changed [19]. Consumers demand to deal with socially responsible companies, which significantly influence their attitudes and behaviors, moreover, they have more and more information and the means to contrast it [20] and the salesperson, as the company's representative, must face it all.

There is some evidence of the positive impact employees' perceptions of CSR on their turnover intention, e.g., [5,8,21,22]. However, according to Sarfraz et al. [5], it needs further research on the perceived CSR-turnover intention relationship. Due to the reasons mentioned above (i.e., the great impact of salespeople turnover and their exposure to customer reactions to the company's behavior), the study of this relationship is of particular interest in the context of sales. A context in which, to the best of our knowledge, the impact of employees' CSR perceptions on their turnover intention has not been analyzed.

Furthermore, previous research on the relationship between CSR and turnover intention has focused on the social exchange theory [8] or the social identity theory [5,22], the two most commonly used theories when explaining the mediating mechanisms of CSR and the employee attitude and behavior relationship $[7,23]$. In this paper, the impact of CSR practices on salesperson turnover intention is analyzed through the lens of the social network theory, see [24] for a revision. In particular, this study analyzes the effect of CSR perception on salesperson turnover mediated by reputation and emotional organizational pride. In addition, it considers the moderating intervention of salespeople's interpersonal justice, but measured from the point of view of their direct supervisors.

This paper contributes to the literature in several ways. Firstly, it expands the social network theory research framework, not only by using it to explain salespeople turnover as Boles et al. [25], but also by using it in the CSR and management context where traditionally other theories, such as social identity theory [26] or social exchange theory [27], are used. Secondly, this study helps to address the shortage of micro-CSR research $[7,11]$. In addition, by including the moderating role of interpersonal justice in the mediated CSR-reputation-organizational pride-turnover intention relationship, we attempt to fill the gap in terms of moderators [7,28]. In his review of micro-CSR literature, Glavas [28] pointed out that only three of the 28 empirical articles on incumbent employees included both mediating and moderating effects together. Thirdly, by analyzing the influence of CSR on salesperson turnover intentions, this study expands the literature on salesperson turnover, an issue that can be very costly for companies [13,29]. Finally, by finding support for most of the proposed hypotheses, and with these outcomes in mind, sales managerial recommendations are proposed.

This study is arranged as follows. After the introduction section, the second section corresponds to the conceptual framework and research hypotheses, some of which refer to mediation and moderation situations. The methodology and results are reported in the third and fourth sections. Finally, the fifth section closes the study with conclusions and discussion.

\section{Theoretical Development}

Social network theory claims that individuals interact and relate to other people and groups through ties of variable degrees of strength, ranging from weak ties to strong ties. This theory can be used to explain how ties between employees and organizations are formed and how they influence employee attitudes and behaviors. Based on this study 
context, i.e., CSR and salespeople context, social network theory can explain how an organization interacts with different groups through CSR, between them the salespeople, but in addition, salespeople interact with those groups (customers, family, local community, etc.) and consequently with the company as well. The connections are based on feelings [30], so if salespeople have a strong connection with any interest group benefited by a company's CSR actions, a strong link with that company will be created. When ties are strong, high emotional closeness occurs and there are situations of reciprocity between the different parties [31]. In this case, the ties created by CSR practices and an organization's reputation generate feelings of organizational pride in salespeople, which will have a positive impact on their intention to remain part of an organization.

\subsection{Salespeople's CSR Perception and Perceived Corporate Reputation}

Corporate reputation is a perception [32] based on the subjective impressions residing in the minds of different stakeholders who are directly or indirectly affected by an organization [33]. Studies on reputation in an employee context have included several perspectives e.g., [34]. However, this study is interested in understanding the interpretation of the perception of organizational reputation as a factor that helps to increase employee connection with a company $[35,36]$ in order to determine how that influences their attitudes.

Organizational reputation therefore defines how external groups view an organization. This perception consequently influences how they see employees working at that company. When employees feel that external parties perceive an organization to have a good reputation, they tend to develop a positive sense of belonging to that group, or in this case, the company [37].

Previous research has analyzed the impact of CSR perceptions on employee perception of organizational reputation [38], and as a result CSR has been acknowledged as one of the most important tools for creating and managing a good corporate reputation $[39,40]$. CSR becomes a source of positive signals for external and internal stakeholders, which are used to build the "reputation of the organization" [41]. One of the main reasons why socially responsible practices are perceived in this way is that they target different interest groups and involve organizational interests beyond economic ones. Therefore, on the basis of these behaviors, a good corporate reputation emerges.

Despite the lack of evidence, this study hopes to find that salespeople's CSR perceptions influence their perception of organizational reputation in the same way. Therefore, the following hypothesis is proposed:

Hypothesis 1 (H1). The perception of CSR is positively related to salespeople's perception of organizational reputation.

\subsection{Salespeople's CSR Perception and Organizational Pride}

Pride is an important emotion for boosting everyday social behavior [42]. Organizational pride implies that individuals develop a sense of self-esteem or pleasure in being members of what they consider a good organization [43]. Based on social network theory, the tie between a company and its salespeople-generated by CSR perception-produces a feeling of organizational pride. Salespeople who belong to a socially responsible company and who are connected with other groups that benefit from those CSR practices are also motivated to feel pride for their company.

The literature has documented the existence of various mechanisms for influencing employee pride $[43,44]$. For example, an organization's moral character as perceived by its employees is one of the most important sources of organizational pride [45]. At this point, it is important to consider the potential effect of socially responsible practices on an organization's business strategy. De Roeck, El Akremi, and Swaen [46] suggest that when employees' CSR perceptions are aligned with their CSR standards, they feel organizational pride. Employees feel better about themselves and, consequently, about the company when 
they feel that they are part of an organization that participates in social, environmental and economic issues [47]. The development of these practices can affect employees' sense of belonging to their company and their self-concept, thereby increasing their sense of pride.

On another level, when employees judge their company's CSR actions positively, they are more likely to feel that their organization is concerned about aspects that go beyond obtaining economic benefits and are more likely to develop a sense of pride in belonging to that organization. Feeling like members of a company that cares about their present and future, beyond profitability, makes employees proud to belong to it [48]. This is similar to when an individual judges the fairness of group processes [49].

In the sales-force field, although there is no evidence, similar behavior is expected. Therefore, this leads to the following hypothesis:

Hypothesis 2 (H2). Salespeople's perception of CSR is positively related to organizational pride.

\subsection{Perceived Reputation and Organizational Pride}

Employees are proud of their company when they consider it to be an organization with prestige, a good image, and a good reputation. Employees who perceive their company as having a good reputation will have an improved feeling of connection with it, and their organizational pride will also be influenced $[35,50]$. Therefore, as a result of the psychological attachment and the sense of joining associated with being part of an organization, salespeople who work in a company with a good reputation tend to have increased organizational pride.

Consequently, the following hypothesis is proposed:

Hypothesis 3 (H3). Perceived reputation is positively related to organizational pride.

\subsection{Organizational Pride and Salesperson Turnover Intention}

Turnover intention can be understood as a conscious and deliberate willingness to leave an organization [51]. The desire to leave an organization may be conditioned by multiple factors: Individual, organizational, work-related, environmental, and psychological [52]. What is clear regarding turnover is that an employee will voluntarily terminate their relationship with an organization, often at a cost to both [53].

Dutton, Dukerich, and Harquail [54] noted that employees who experience organizational pride might be more likely to remain in their company, resulting in lower turnover intention. Individuals have improved perceptions of their organization's behavior when they feel a connection with it. This improvement could result, for example, from their shared ways of doing things and of dealing with facts. If employees experience organizational pride, their attitudes toward their organization may be more positive, thereby increasing the probability that the employees will remain in the company. In the same way, Gouthier and Rhein [55] suggest that if employees are proud to be part of the organization in which they work, they will show a positive attitude toward their work, which will negatively influence their intention to voluntarily leave their company.

Therefore, the following hypothesis is proposed:

Hypothesis 4 (H4). Organizational pride is negatively related to salesperson turnover intention.

\subsection{Turnover Intention: Mediation Hypotheses}

Building on the previous arguments, this paper proposes that CSR perceptions, if positive, are a good instrument to generate organizational reputation $[39,40]$ and a sense of organizational pride [46] among employees. Organizational pride increases when there is a positive judgment about a company's reputation [35,50]. In sum, good CSR perceptions strengthen the bond between individuals and their organizations and consequently, salespeople will develop attitudes and behaviors that are beneficial to a company. This phenomenon is explained by the theoretical framework of social network theory. When 
employees feel proud of their organization, their sense of belonging and commitment improves and, as a result, their intention to leave their company is reduced.

Based on these arguments, the following is proposed:

Hypothesis 5 (H5). Salespeople's CSR perception negatively influences their turnover through the sequential mediation of perceived organizational reputation and organizational pride.

\subsection{Interpersonal Justice: Moderation Hypothesis}

According to Hacker-Wright [56], the virtue of justice compels individuals to be concerned about vulnerable things or creatures. This concern implies a willingness to eliminate or reduce inequalities or unjust situations as much as possible [57]. From this perspective, to act under the virtue of justice is to achieve equality in every situation in daily life. Those who possess this virtue also tend to be in a position to increase the capabilities of individuals [57]. Individuals who are considered to possess a high sense of justice are understood to achieve excellence [58]. Following Colquitt [59], interpersonal justice can be understood as a virtue related to the extent to which an individual will treat another with dignity, respect, and politeness.

To date, the academic literature in the organizational field has dealt extensively with justice from an organizational standpoint, i.e., employees' or other stakeholders' perception of whether an organization with which they deal is fair and treats them fairly [59-62] however, little attention has been devoted to an organization's nature as a virtue. Even so, some authors consider that within organizational justice, the interpersonal justice componentwhich has clear nuances-could be related to the virtue of justice. Interpersonal justice is understood as having respect for the persons involved in decision-making i.e., it is measured by the degree to which, during a decision-making process, the persons involved are treated with respect and dignity [63,64].

Since previous studies have shown the positive relationship between interpersonal justice and CSR, this work focuses on that individual-level construct. There are several studies linking CSR and justice. Aguinis and Glavas [6] and Rupp et al. [65] suggest that an employee's response to CSR practices depends on their perception of how fairly or unfairly they are treated in their company. However, recent studies suggest that interpersonal justice is more psychologically meaningful to employees than other kinds of justice, such as distributive or procedural [66]. Therefore, this paper proposes that employees who have high standards of justice will feel better in companies that develop practices based on principles of justice, for example, by engaging in socially responsible activities. This in turn will influence salespeople's emotional organizational pride, followed by their attitudes and behaviors. For an individual with high standards of justice, the relationship between CSR perceptions and the results derived from these perceptions (i.e., organizational pride) is more positive. There is evidence that perceptions of justice are positively related to employees' sense of pride [67].

Consequently, the following hypothesis is proposed:

Hypothesis 6 (H6). Interpersonal justice moderates the relationship between salespeople's CSR and their sense of pride. In short, the impact of CSR perception on a salesperson's turnover through organizational reputation and organizational pride is stronger when the salesperson has a high level of interpersonal justice and is weaker when the salesperson has a low level of interpersonal justice.

A brief overview of the previous hypothesized connections is further elaborated in our proposed model for evaluating the nexus between CSR perception and salespeople turnover intention (see Figure 1). The figure describes the moderated mediation model. It is comprised of a total of five constructs, where CSR perception is the independent variable, and turnover is the dependent. At the same time, the constructs reputation and organizational pride intervene as mediators and interpersonal justice as moderator. As indicated in the figure's legend, with the exception of interpersonal justice, all variables 
have been self-evaluated by the vendors. While interpersonal justice was assessed by their direct supervisors.

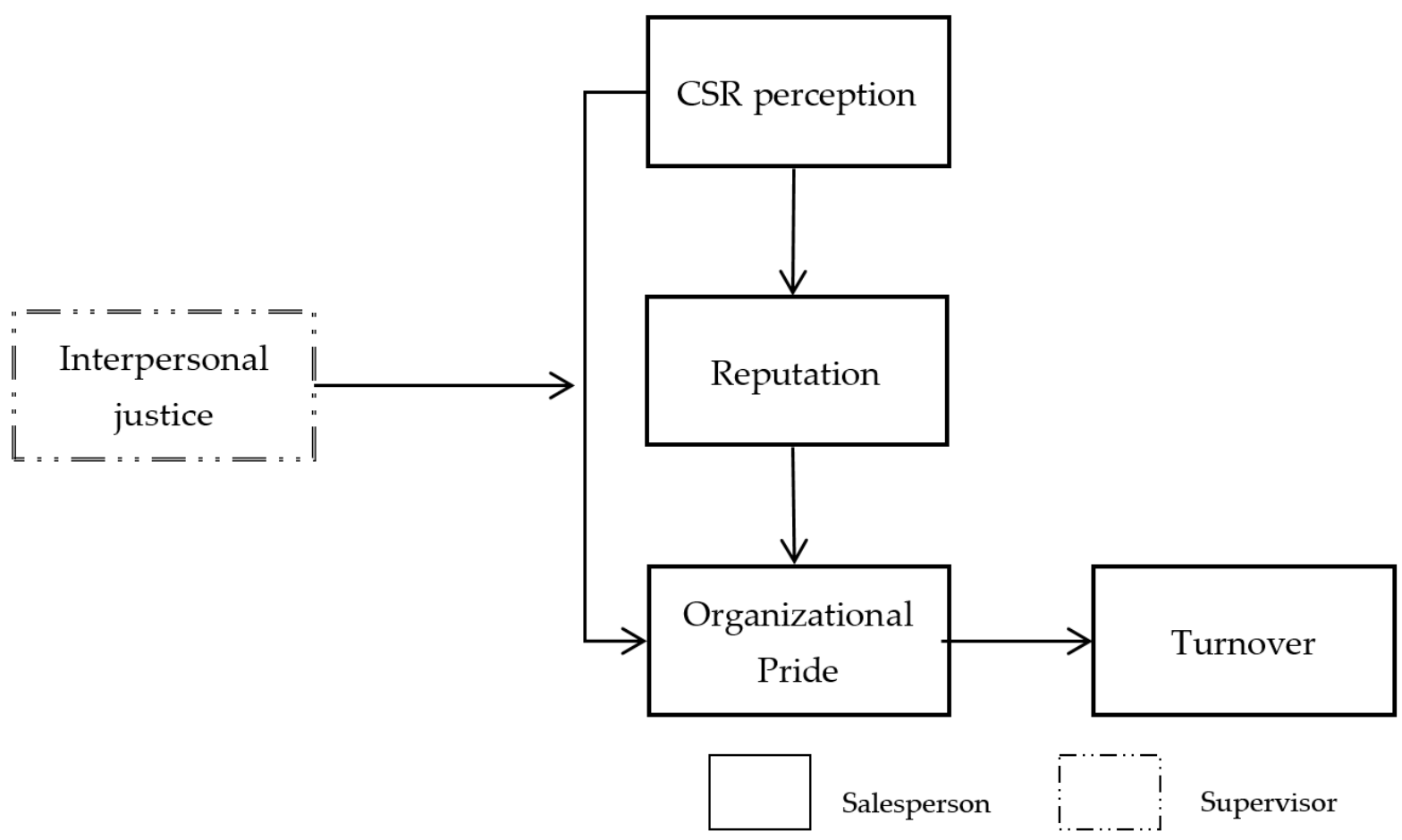

Figure 1. Proposed model. Source: Authors' elaboration.

\section{Methodology}

\subsection{Data Collection Procedure and Sources}

The data comes from 176 supervisor-salesperson dyads (composed of a ratio of almost 1:1) who worked at 96 Spanish companies from 11 activity sectors, including banking services, the automobile industry, the pharmaceutical industry, etc. Respondents answered a personal questionnaire which their sales manager or human resources representative gave them. Previously, this study's researchers had contacted those managers by e-mail or telephone to explain their objectives. Once managers had agreed to participate, the researchers gave them the questionnaires in person.

The supervisor sample is made up of $67.6 \%$ males and $32.4 \%$ females. They have an average age of 43 years, have more than 10 years of experience in a sales position, and have been working for their companies for an average of 15 years. The salespeople sample is made up of $55.1 \%$ females with an average age of 41 years, a mean sales experience of 14 years, and a mean organizational tenure of 10 years. Thus, the sample is composed of experienced salespeople, which is consistent with similar studies on the consequences of employee perceptions of CSR and which report a moderately high employee average job tenure $[68,69]$.

The salespeople provided ratings of CSR perceptions, organizational reputation, organizational pride, and control variables. The supervisors provided ratings of each subordinate's interpersonal justice.

\subsection{Measures}

To measure the variables, 7-point scales ranging from 1 (strongly disagree) to 7 (strongly agree) were used. The original scales are written in English, so Brislin's methodology [70] was employed to translate them into Spanish. In the pretest (with a sample of five pairs of questioners), it was found that respondents were unable to adequately assess the two items that measure the governmental dimension of Turker's [71] CSR scale. Those 
items refer to paying taxes and complying with legal regulations, which do not fit with a CSR definition based on voluntary corporate actions. Therefore, the CSR to government dimension was not included in the study.

Turker's [71] three dimensional scale was used to measure CSR. It was composed of 14 items: 6 items to measure the social/environmental/NGO dimension, 5 items to measure the employee dimension, and 3 items to measure the customer dimension. Their respective Cronbach's alpha values were 0.94, 0.90, and 0.70 and the overall scale had a Cronbach's alpha value of 0.79 .

Organizational reputation was measured with a 4-item scale developed by Ahearne, Mathieu, and Rapp [72] and its Cronbach's alpha was 0.91. Organizational pride, a 3-item scale created by Gouthier and Rhein [55] was used and had a Cronbach's alpha of 0.93. Turnover was measured with a 3-item scale proposed by Fournier et al. [73]. Its Cronbach's alpha was 0.92 .

Supervisors were asked to indicate their perception of the salesperson's interpersonal justice. Colquitt's [59] 4-item scale was used to measure that variable, and its Cronbach's alpha was 0.87 .

Salespeople's demographic aspects can influence the relationships between the study variables, so as in other studies $[3,46]$ the gender and age of the sellers have been included as control variables.

\subsection{Measurement Model (Scale Validity and Reliability)}

IBM SPSS AMOS program was used to conduct the confirmatory factor analysis (CFA). It confirmed that all indicators loaded substantially $(>0.5)$ and significantly $(p<0.05)$ on their respective constructs, confirming the existence of convergent validity. The model fit presented acceptable values $\left(X^{2}=608.56\right.$, d.f. $=333, p<0.001$, root mean square error of approximation-RMSEA $=0.07$, comparative fit index-CFI $=0.93$, incremental fit index-IFI = 0.93, Tucker-Lewis index-TLI $=0.92$ ).

Additionally, the composite reliability index and extracted variance index exceeded critical values of 0.7 and 0.5 , respectively [74]. Fornell and Larcker's [75] approach was used to asses discriminant validity.

Table 1 shows the means, standard deviations, and bivariate correlations of all 5 constructs and 2 control variables used in the conceptual model. Pearson's correlation coefficients are used in order to assess the strength of the relationship between the constructs used on the proposed model. The results of Pearson's coefficient show that CSR is positively correlated with reputation $(\mathrm{r}=0.59, p<0.01)$, pride $(\mathrm{r}=0.53, p<0.01)$, and is negatively correlated with turnover $(r=-0.21, p<0.01)$. Reputation was positively correlated with pride $(\mathrm{r}=0.63, p<0.01)$ and negatively with turnover $(\mathrm{r}=-0.26, p<0.01)$. Finally, pride is negatively correlated with turnover $(\mathrm{r}=-0.38, p<0.01)$.

Table 1. Means, standard deviations, and correlations among variables.

\begin{tabular}{lcccccccc}
\hline & Mean & S.D. & $\mathbf{1}$ & $\mathbf{2}$ & $\mathbf{3}$ & $\mathbf{4}$ & $\mathbf{5}$ & $\mathbf{6}$ \\
\hline 1. CSR & 5.38 & 0.97 & & & & & & \\
2. Reputation & 5.67 & 1.05 & $0.59 * *$ & & & & & \\
3. Pride & 5.85 & 1.18 & $0.53 * *$ & $0.63 * *$ & & & & \\
4. Justice & 6.33 & 0.79 & 0.09 & 0.06 & 0.11 & & & \\
5. Turnover & 2.36 & 1.65 & $-0.21^{* *}$ & $-0.26^{* *}$ & $-0.38^{* *}$ & -0.05 & & \\
6. Gender & 1.55 & 0.50 & -0.05 & -0.05 & -0.10 & -0.01 & -0.01 & \\
7. Age & 41.13 & 8.74 & 0.01 & 0.01 & 0.04 & -0.10 & -0.04 & $-0.21^{* *}$ \\
\hline${ }^{* *} p<0.01$ Source: Authors' calculation. Corporate social responsibility (CSR). & & &
\end{tabular}

\subsection{Common Method Variance Bias and Multicollinearity}

To control the occurrence (or absenteeism) of potential common method variance (CMV) bias, a combination of approaches was used. On the one hand, the questionnaire was designed to prevent the introduction of complex factors that might limit the respondents' capacity to answer accurately, thereby reducing potential sources of method bias, the 
indicators of the model variables were included in different sections of the questionnaire and the interviewees were ensured that their answers would remain anonymous [76]. On the other hand, a CFA approach to Harman's one-factor test to assess whether a single latent factor accounted for all manifested variables [77] was used. The outcomes of the single-factor CFA model were compared to those of the multifactor measurement model in which all indicators loaded on their corresponding constructs, and the outcomes suggested that CMV was not thought to be a risk in this study.

The variance inflation factor (VIF) was used to evaluate the presence of multicollinearity among variables. VIFs ranged from 1.64 to 1.94 , providing evidence that multicollinearity was not a problem in this study.

\section{Results}

To test the mediation and moderation hypotheses, serial multiple mediation analysis and conditional process analysis [78] were used, both were based on multiple regression analysis by ordinary least squares.

Specifically, Model 6 [78] (see Figure A1 on Appendix A to know model development) and PROCESS macro for SPSS program was used for the mediation analysis. This model, which has two mediating variables and proposes that variable $\mathrm{X}$ (CSR) influences variable Y (turnover) through variables M1 (reputation) and M2 (pride), thereby collecting four possible effects (one direct effect and three indirect effects).

Model 7 [78] (see Figure A2 on Appendix A to know model development), a conditional process model, was used for the moderation analysis as presented in hypotheses 6 , with $\mathrm{X}$ being the CSR variable, M1 being pride, $\mathrm{W}$ being interpersonal justice, $\mathrm{Y}$ being turnover, and reputation being a covariate. In this way, it is possible to not only compare whether the relationship between CSR and pride is contingent on interpersonal justice but also to estimate whether the indirect effects of CSR on turnover, through pride, depend on interpersonal justice. To avoid interpretation problems with certain coefficients and given the measurement scales of certain considered variables (which do not include the value zero), the interaction term variables are focused on the mean centered. Likewise, in the mediation and moderation analyses, gender and age control variables are included.

Table 2 shows the non-standardized regression estimates. The results indicate that CSR perception positively influences the company's reputation $(\mathrm{a} 1=0.63, p<0.001)$ and, in turn, organizational pride $(\mathrm{d} 21=0.54, p<0.001)$, which has a negative and significant effect on a salesperson's intention to leave a company (b2 $=-0.49, p<0.001$ ). These results support hypotheses 1,3 , and 4 . Moreover, CSR has a positive and significant effect on pride $(\mathrm{a} 2=0.30, p<0.001)$, which supports hypothesis 2 .

Table 2. Model coefficients for the conditional process analysis in the mediation.

\begin{tabular}{ccccccccccc}
\hline & \multicolumn{10}{c}{ Consequences (Model 6) } \\
\cline { 2 - 11 } Antecedents & Coeff. & SE & $p$ & Coeff. & SE & $p$ & Coeff. & SE & $p$ \\
\hline Constant & 2.33 & 0.56 & $<0.001$ & 1.28 & 0.61 & 0.04 & 6.15 & 1.06 & $<0.001$ \\
CSR & 0.63 & 0.07 & $<0.001$ & 0.30 & 0.09 & $<0.001$ & 0.01 & 0.15 & 0.96 \\
Reputation & - & - & - & 0.54 & 0.08 & $<0.001$ & -0.06 & 0.15 & 0.68 \\
Pride & - & - & - & - & - & - & -0.49 & 0.13 & $<0.001$ \\
Control Variables & Coeff. & SE & $\boldsymbol{p}$ & Coeff. & SE & $\boldsymbol{p}$ & Coeff. & SE & $p$ \\
Gender & -0.04 & 0.13 & 0.74 & -0.13 & 0.14 & 0.35 & -0.18 & 0.24 & 0.46 \\
Age & 0.00 & 0.01 & 0.98 & 0.00 & 0.01 & 0.32 & -0.01 & 0.01 & 0.59 \\
R-squared & & 0.35 & & & 0.35 & & & 0.15 & \\
F & & 30.37 & & & 30.37 & & & 5.77 & \\
$p$ value & & $<0.001$ & & & $<0.001$ & & & $<0.001$ & \\
\hline
\end{tabular}

Note: Each column is a regression model that predicts the criterion at the top of the column. The Coefficient (Coeff.) values are standardized coefficients, thus they determine the relative strength of different variables in the model. Source: Authors' calculation. 
The results show that there is no direct relationship between CSR perception and the turnover intention (see Table 3). However, they do confirm two indirect means of influence, which are that CSR perception influences salesperson turnover via the mediator, organizational pride, and via the two mediators, reputation, and organizational pride. Therefore, the two variables proposed in the model are confirmed as mediators, but the results highlight the importance of organizational pride since it is the mechanism through which the two indirect effects of CSR on turnover occur.

Table 3. Direct and indirect effects of CSR perception on turnover.

\begin{tabular}{cccccc}
\hline Direct effect & Effect & SE & $p$ & LLCI & ULCI \\
\hline CSR-> Turnover & 0.01 & 0.15 & 0.95 & -0.29 & 0.31 \\
\hline Indirect effect & Effect & BootSE & $p$ & BootLLCI & BootULCI \\
\hline CSR-> Reputation-> Turnover & -0.04 & 0.11 & & -0.61 & -0.15 \\
CSR-> Reputation->Pride->Turnover & -0.17 & 0.11 & & -0.34 & -0.07 \\
CSR->Pride-> Turnover & -0.15 & 0.07 & & -0.32 & -0.05 \\
\hline Total effect & Effect & SE & $p$ & LLCI & ULCI \\
\hline CSR->Turnover & -0.35 & 0.13 & 0.01 & -0.60 & -0.10 \\
\hline
\end{tabular}

Source: Authors' calculation.

The contrast of Model 7 [78] confirms that interpersonal justice moderates the relationship between CSR and organizational pride, but not in the expected sense (a21 $=-0.19$, $p<0.02)$ : The higher the level of a salesperson's interpersonal justice, the smaller the positive influence of CSR on organizational pride (see Table 4).

Table 4. Model coefficients for the conditional process analysis in the moderation.

\begin{tabular}{ccccccc}
\hline & \multicolumn{5}{c}{ Consequences (Model 7) } \\
\cline { 2 - 7 } Antecedents & Coeff. & M2 (Pride) & $p$ & Coeff. & SE & $p$ \\
\hline Constant & 2.96 & 0.62 & $<0.001$ & 6.20 & 1.15 & $<0.001$ \\
CSR & 0.29 & 0.09 & $<0.001$ & 0.01 & 0.15 & 0.96 \\
Reputation & 0.51 & 0.08 & $<0.001$ & -0.06 & 0.15 & 0.68 \\
Pride & - & - & - & -0.49 & 0.13 & $<0.001$ \\
Justice & 0.08 & 0.09 & 0.33 & - & - & - \\
CSR x interpersonal justice & -0.19 & 0.08 & 0.02 & - & - & - \\
Control variables & Coeff. & SE & $p$ & Coeff. & SE & $p$ \\
Gender & -0.09 & 0.14 & 0.51 & -0.18 & 0.24 & 0.46 \\
Age & 0.00 & 0.01 & 0.63 & -0.01 & 0.01 & 0.59 \\
R-squared & & 0.68 & & & 0.38 & \\
F & & 23.84 & & & 5.77 & $<0.001$ \\
value & & $<0.001$ & & & & \\
\hline
\end{tabular}

Note: Each column is a regression model that predicts the criterion at the top of the column. The Coefficient (Coeff.) values are standardized coefficients, thus they determine the relative strength of different variables in the model. Source: Authors' calculation.

None of the control variables were found to have a significant effect on the dependent variables.

On the other hand, conditional process analysis using a bootstrapping technique allowed the confidence intervals for indirect effects [78,79] to be calculated. Table 5, which shows the conditional indirect effects of CSR perception on the intention to leave a company for different interpersonal justice values, indicates that the indirect effect of CSR perception on turnover is conditioned by a salesperson's interpersonal justice. 
Table 5. Indirect effects.

\begin{tabular}{cccccc}
\hline Indirect Effect & Justice Values & Effect & Boot SE & LLCI * & ULCI ** \\
\hline CSR->Pride-> Turnover & 5.25(Percentile10) & -0.25 & 0.10 & -0.50 & -0.09 \\
& 6.00(Percentile 25) & -0.17 & 0.07 & -0.36 & -0.06 \\
& 6.50(Percentile 50) & -0.13 & 0.06 & -0.29 & -0.03 \\
& 7.00(Percentile 75) & -0.08 & 0.06 & -0.24 & 0.02 \\
& 7.00(Percentile 90) & -0.08 & 0.06 & -0.24 & 0.02 \\
\hline
\end{tabular}

${ }^{*}$ Lower limit confidence interval, ${ }^{* *}$ Upper limit confidence interval. Source: Authors' calculation.

Based on the bootstrap estimation of the confidence intervals with a $95 \%$ bias correction and 5000 boot samples, it was observed that when interpersonal justice takes values below the 6.50th percentile (50th percentile), the indirect influence of CSR on turnover via organizational pride is not significant, since the confidence interval includes zero. For low interpersonal justice values, the indirect effect of CSR on turnover through organizational pride depends on a salesperson's degree of fairness. The lower the level of interpersonal justice, the greater the negative CSR impact on turnover. In other words, the fairer the salesperson, the less negative the CSR impact is on abandonment. This effect is not significant for high values (above 6.5) of interpersonal justice.

Figure 2 presents a graph produced using Dawson's [80] process. It shows a slightly positive slope for high interpersonal justice values and a more pronounced positive slope for low interpersonal justice values. Therefore, for high interpersonal justice values, organizational pride is similarly influenced by high or low CSR values. However, in situations of low interpersonal justice, CSR has a more pronounced positive influence on pride.

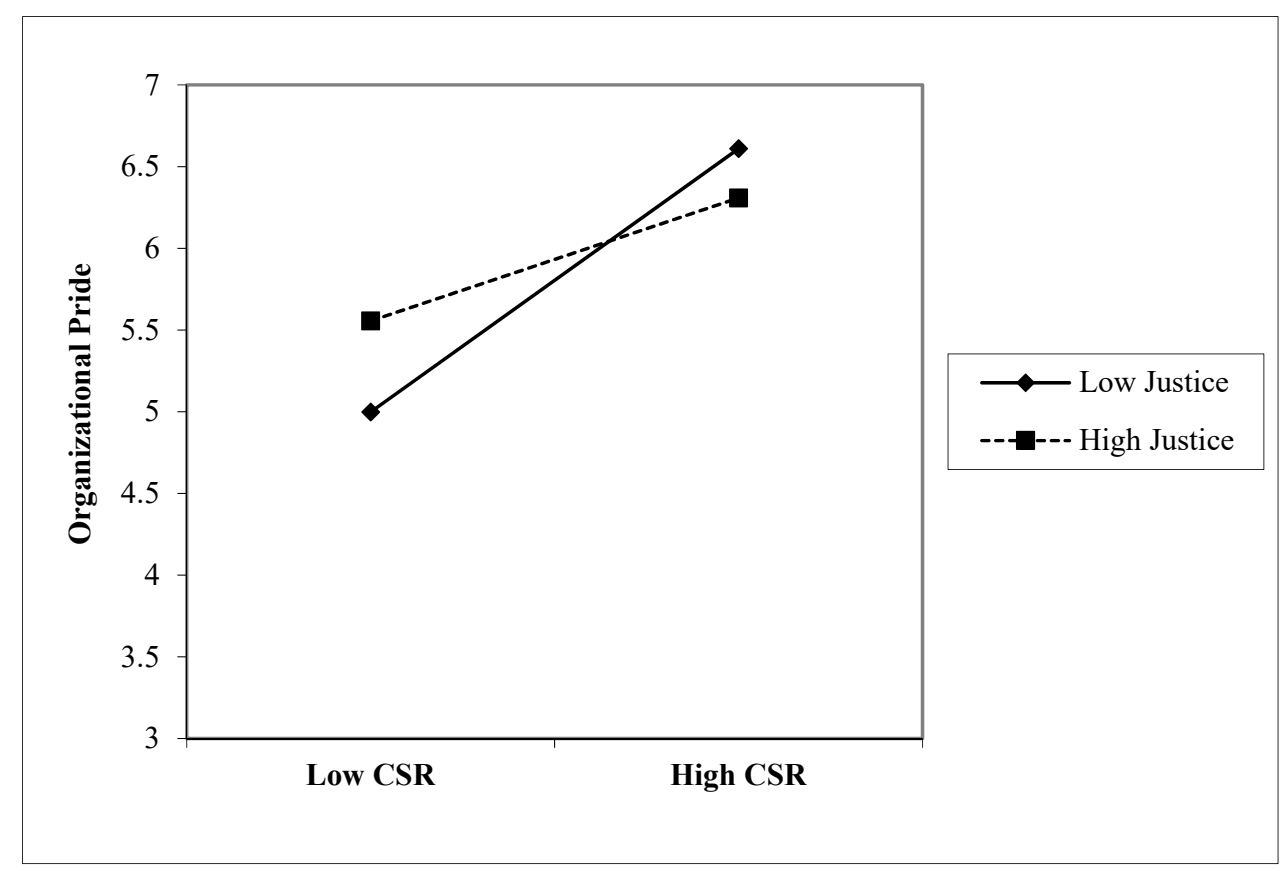

Figure 2. Moderating effect of interpersonal justice. Source: Authors' elaboration.

\section{Discussions and Conclusions}

\subsection{Theoretical Implications}

Decreasing high salesperson turnover rates is a key issue for many organizations [13,29]. This paper analyzes how salespeople's perception of socially responsible practices influences their turnover intention and considers the mediating role of the organization's reputation and the emotional organizational pride felt by its salespeople. It also considers the moderating role of the salesperson's degree of fairness. To this end, a model with mediating and moderating effects was proposed and the results indicate that CSR perceptions diminish the intention to leave a company, in a sales context, through the positive 
perceptions of organizational reputation and emotional organizational pride. This can be explained through the social network theory, which suggests that by connecting with different groups to a greater or lesser extent, employees and, in this case, salespeople develop feelings that influence their attitudes and behaviors.

The study confirms the existence of a direct and positive relationship between CSR perceptions and the company's reputation. Companies that carry out this type of practice generate a positive perception of themselves in the external and internal public (i.e., a reputation that is perceived as good). This good reputation triggers other positive results. These findings are in line with previous research e.g., [41], according to which organizational reputation mediates the relationship between CSR and variables such as job satisfaction or employee organizational commitment. However, to the best of our knowledge, this work is the first study to show that organizational reputation mediates the connection between CSR perceptions and salespeople's emotional organizational pride.

Similarly, the study suggests that salespeople's perceptions of socially responsible practices are directly related to organizational pride. This finding implies that a salesperson is proud when they see that their company contributes to social and environmental causes, cares about customers, or pays attention to their own needs. Thus, sales managers and/or CSR managers should not underestimate the significant psychological impact that this type of practice has on salespeople.

Making salespeople proud of their organization through a good perception of socially responsible practices, as well as through a good reputation, is important to reducing their intention to leave the company.

The findings also clarify the conditions or circumstances under which CSR influences salesperson turnover. The investigation of such conditions has been mentioned as one of the most important research gaps [7,28]. Relying on this perspective, this study considered that interpersonal justice interacts to strengthen the CSR effect on reducing turnover intention. It had been hypothesized that when a salesperson is fair and considers that justice is a value that governs CSR, they will value their company's socially responsible actions more positively and, therefore, their feeling of organizational pride will be greater. However, the results confirm that the fairer a person is, the weaker the relationship between CSR perception and organizational pride.

This surprise result can be read as follows. From a theoretical point of view, it can be explained by the Three-Part Theory of Justice [81] that suggests individuals can classify a situation or fact in which a third party is involved as fair, on the basis of three principles: Equality, necessity, and/or equity [82]. Depending on the nature of CSR, it can be expected that employees and, in this case, salespeople value that everyone is treated equally (principle of equality) or that the neediest benefit from socially responsible actions (principle of necessity) however, individuals usually prefer that the reward is proportional to the effort made (principle of equity). In the latter case, individuals tend to think that they deserve the greatest reward. If they see that someone else receives a reward, they could see the situation as unfair. Therefore, this could indicate that their company's CSR strategy is too focused on external stakeholders rather than on internal stakeholders, i.e., themselves, which could negatively affect their attitudes and behavior.

However, due to a lack of data relating to the salespeople's perception of who benefits from CSR activities, it has not been possible to examine this argument in this study. Thus, these unexpected results have an implication for future research.

\subsection{Managerial Implications}

This paper also has some practical implications and suggests that sales managers can reduce salesperson turnover intention through CSR practices. It is particularly important that efforts are made to ensure that the perception of these practices is positive and that it is viewed positively by both external and internal stakeholders therefore, organizations must communicate CSR efforts appropriately to stakeholders [83], particularly, in this situation, to salespeople. To this end it could be through useful new technologies, so managers should 
pay attention to big data and digitalization in the field of sustainability [84]. Improved communication efforts will influence the reputation earned by a company and will affect salespeople's organizational pride. It is also important for managers to pay particular attention to how they perceive CSR and how they would like to be influenced by this type of practice. In this way, the ways in which virtuous people and people with high moral standards perceive CSR and how this affects their behavior and attitudes could be better understood.

On this last point, it would also be useful for those responsible for a company's CSR or, failing that, sales managers to convey the fundamentals of socially responsible behavior to their salespeople. Employees may thus have a better understanding of such practices and may feel that the benefits obtained are as beneficial to them as they should be, their behavioral and attitudinal outcomes may be positively affected.

\subsection{Limitations and Future Lines of Research}

Notwithstanding its contributions, this study is not without its limitations. Firstly, the cross-sectional nature of the data and its collection in a national context make it difficult to generalize the results and extract from this study assumptions about the nature of the causal relationships raised in the model [85]. Future studies should try to replicate it at different times as well as extend it to other social, economic, and cultural contexts. Furthermore, researchers should try to conduct longitudinal studies, which would provide more insight into how changes in salespeople's CSR perceptions depend on changes in salesperson turnover intentions and attitudes.

Secondly, the model's variables are perceptions of a salesperson or their supervisor. In the case of CSR practices, future studies should check whether these perceptions are indeed in line with the real initiatives developed by a company. Regrettably, information about the companies' CSR activities in the sample is unavailable. To obtain this data, the researchers would have had to have received it directly from the organizations' managers, which was impossible.

Thirdly, this study considers only two variables as mediators of the connection between CSR and the intention to leave a company. Other studies should consider more variables that complement this work's results. For example, it would be convenient to consider corporate image or the perception of external prestige. These are two variables that are often used interchangeably to discuss about organizational reputation but have different nuances therefore, they may be affected differently by the perception of socially responsible initiatives and, in effect, have different results.

Finally, although previous studies show that, in the Spanish context, the employees personal or situational characteristics are not related to the assessment or perception of CSR practices, even in key positions within the organization such as managers [86] or leaders [87], the experience of salespeople has been linked to different work outcomes [88]. Thus, when replicating the proposed relationships in other contexts, future research would benefit from including sales experience as a control variable.

Author Contributions: Conceptualization, S.C.-G., B.B. and G.V.-V.; methodology, B.B. and G.V.-V.; software, B.B. and G.V.-V.; validation, S.C.-G., B.B. and G.V.-V.; formal analysis, B.B.; investigation, S.C.-G.; resources, S.C.-G.; data curation, S.C.-G.; writing-original draft preparation, S.C.-G., B.B. and G.V.-V.; writing-review and editing, and S.C.-G., B.B. and G.V.-V.; visualization, S.C.-G., B.B. and G.V.-V.; supervision, S.C.-G., B.B. and G.V.-V.; project administration, S.C.-G. and B.B; funding acquisition, S.C.-G. All authors have read and agreed to the published version of the manuscript.

Funding: This research was funded by Galician Plan for Research, Innovation and Growth (Plan I2C) of the Xunta de Galicia (Consellería de Cultura, Educación y Ordenación Universitaria).

Informed Consent Statement: Informed consent was obtained from all subjects involved in the study.

Data Availability Statement: The data presented in this study are available on request from the corresponding author. The data are not publicly available due to restrictions of privacy. 
Conflicts of Interest: The authors declare no conflict of interest.

Appendix A

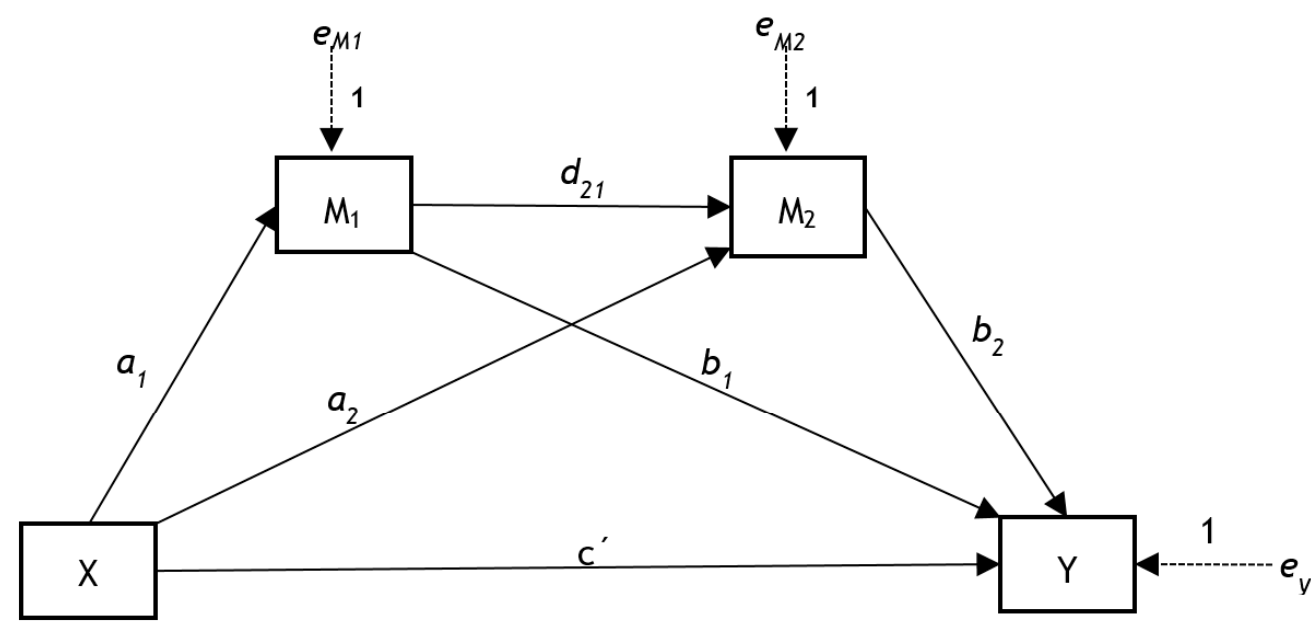

*Indirect effect of $\mathrm{X}$ on $\mathrm{Y}$ through $M_{i}=a_{i} b_{i}$

Indirect effect of $X$ on $Y$ through $M_{1} M_{2}=a_{1} d_{21} b_{2}$

Figure A1. Statistical diagram of model 67 of the process for SPSS program.

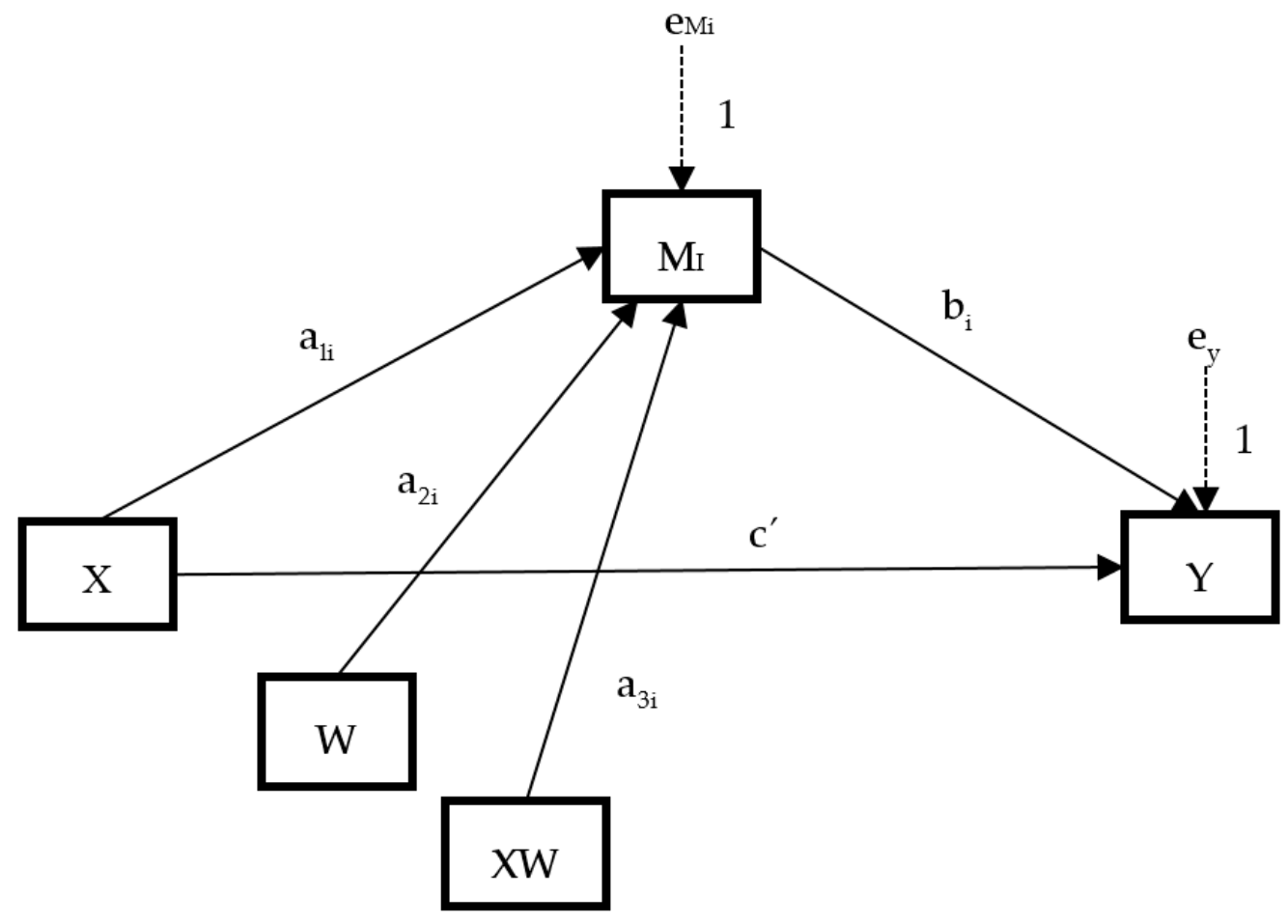

Conditional indirect effect of X on Y through $M_{l}=\left(a_{1 i}+a_{3 i} W\right) b_{i}$

Direct effect of $\mathrm{X}$ on $\mathrm{Y}=c^{\prime}$

Figure A2. Statistical diagram of model 7 of the process for SPSS program. 


\section{References}

1. Aguinis, H. Organizational responsibility: Doing good and doing well. In Maintaining, Expanding, and Contracting the Organization. APA Handbooks in Psychology; American Psychological Association: Washington, DC, USA, 2011; pp. 855-879.

2. El Akremi, A.; Gond, J.-P.; Swaen, V.; De Roeck, K.; Igalens, J. How Do Employees Perceive Corporate Responsibility? Development and Validation of a Multidimensional Corporate Stakeholder Responsibility Scale. J. Manag. 2015. [CrossRef]

3. John, A.; Qadeer, F.; Shahzadi, G.; Jia, F. Getting paid to be good: How and when employees respond to corporate social responsibility? J. Clean. Prod. 2019, 215, 784-795. [CrossRef]

4. Lee, L.; Chen, L.-F. Boosting employee retention through CSR: A configurational analysis. Corp. Soc. Responsib. Environ. Manag. 2018, 25, 948-960. [CrossRef]

5. Sarfraz, M.; Qun, W.; Abdullah, M.; Alvi, A. Employees' Perception of Corporate Social Responsibility Impact on Employee Outcomes: Mediating Role of Organizational Justice for Small and Medium Enterprises (SMEs). Sustainability 2018, 10, 2429. [CrossRef]

6. Aguinis, H.; Glavas, A. What We Know and Don't Know About Corporate Social Responsibility: A Review and Research Agenda. J. Manag. 2012, 38, 932-968. [CrossRef]

7. Gond, J.-P.; El Akremi, A.; Swaen, V.; Babu, N. The psychological microfoundations of corporate social responsibility: A personcentric systematic review. J. Organ. Behav. 2017, 38, 225-246. [CrossRef]

8. Farooq, M.; Farooq, O.; Cheffi, W. How Do Employees Respond to the CSR Initiatives of their Organizations: Empirical Evidence from Developing Countries. Sustainability 2019, 11, 2646. [CrossRef]

9. Bourdeau, B.; Graf, R.; Turcotte, M.-F. Influence of Corporate Social Responsibility as Perceived By Salespeople On Their Ethical Behaviour, Attitudes And Their Turnover Intentions. J. Bus. Econ. Res. 2013, 11, 353-366. [CrossRef]

10. Vlachos, P.A.; Theotokis, A.; Panagopoulos, N.G. Sales force reactions to corporate social responsibility: Attributions, outcomes, and the mediating role of organizational trust. Ind. Mark. Manag. 2010, 39, 1207-1218. [CrossRef]

11. Ng, T.W.H.; Yam, K.C.; Aguinis, H. Employee perceptions of corporate social responsibility: Effects on pride, embeddedness, and turnover. Pers. Psychol. 2019, 72, 107-137. [CrossRef]

12. Sunder, S.; Kumar, V.; Goreczny, A.; Maurer, T. Why Do Salespeople Quit? An Empirical Examination of Own and Peer Effects on Salesperson Turnover Behavior. J. Mark. Res. 2017, 54, 381-397. [CrossRef]

13. Benoit, I.D.; Brashear Alejandro, T.; Foreman, J.; Chelariu, C.; Bergman, S. Social norms in the salesforce: Justice and relationalism. J. Bus. Ind. Mark. 2019, 34, 49-61. [CrossRef]

14. Jaramillo, F.; Mulki, J.P.; Solomon, P. The role of ethical climate on salesperson's role stress, job attitudes, turnover intention, and job performance. J. Pers. Sell. Sales Manag. 2006, 26, 271-282. [CrossRef]

15. DeConinck, J.B.; Johnson, J.T. The Effects of Perceived Supervisor Support, Perceived Organizational Support, and Organizational Justice on Turnover among Salespeople. J. Pers. Sell. Sales Manag. 2009, 29, 333-350. [CrossRef]

16. Comaford, C. Salespeople Are Burning out Faster than Ever-Here's Why. Available online: https://www.forbes.com/sites/ christinecomaford/2016/06/18/how-leaders-can-engage-retain-top-sales-talent/ (accessed on 18 December 2020).

17. Hansen, J.D.; Riggle, R.J. Ethical Salesperson Behavior in Sales Relationships. J. Pers. Sell. Sales Manag. 2009, 29, 151-166. [CrossRef]

18. Ferrell, O.C.; Johnston, M.W.; Marshall, G.W.; Ferrell, L. A New Direction for Sales Ethics Research: The Sales Ethics Subculture. J. Mark. Theory Pract. 2019, 27, 282-297. [CrossRef]

19. Zhang, A.L.; Baxter, R.; Glynn, M.S. How salespeople facilitate buyers' resource availability to enhance seller outcomes. Ind. Mark. Manag. 2013, 42, 1121-1130. [CrossRef]

20. Pantano, E.; Priporas, C.-V. The effect of mobile retailing on consumers' purchasing experiences: A dynamic perspective. Comput. Hum. Behav. 2016, 61, 548-555. [CrossRef]

21. Kim, J.; Song, H.J.; Lee, C.-K. Effects of corporate social responsibility and internal marketing on organizational commitment and turnover intentions. Int. J. Hosp. Manag. 2016, 55, 25-32. [CrossRef]

22. Wang, W.; Fu, Y.; Qiu, H.; Moore, J.H.; Wang, Z. Corporate Social Responsibility and Employee Outcomes: A Moderated Mediation Model of Organizational Identification and Moral Identity. Front. Psychol. 2017, 8, 1906. [CrossRef]

23. Jones, D.A.; Newman, A.; Shao, R.; Cooke, F.L. Advances in Employee-Focused Micro-Level Research on Corporate Social Responsibility: Situating New Contributions within the Current State of the Literature. J. Bus. Ethics 2019, 157, 293-302. [CrossRef]

24. Liu, W.; Sidhu, A.; Beacom, A.M.; Valente, T.W. Social Network Theory. In The International Encyclopedia of Media Effects; John Wiley \& Sons, Inc.: Hoboken, NJ, USA, 2017; pp. 1-12.

25. Boles, J.S.; Dudley, G.W.; Onyemah, V.; Rouziès, D.; Weeks, W.A. Sales Force Turnover and Retention: A Research Agenda. J. Pers. Sell. Sales Manag. 2012, 32, 2012. [CrossRef]

26. Tajfel, H.; Turner, J.C. An integrative theory of intergroup conflict. In The Social Psychology of Intergroup Relations; Oxford University Press: New York, NY, USA, 1979; pp. 33-47.

27. Emerson, R.M. Social Exchange Theory. Annu. Rev. Sociol. 1976, 2, 335-362. [CrossRef]

28. Glavas, A. Corporate Social Responsibility and Organizational Psychology: An Integrative Review. Front. Psychol. 2016, 7, 1-13. [CrossRef] [PubMed]

29. Badrinarayanan, V.; Gupta, A.; Chaker, N.N. The pull-to-stay effect: Influence of sales managers' leadership worthiness on salesperson turnover intentions. J. Pers. Sell. Sales Manag. 2020, 1-17. [CrossRef] 
30. Hansen, H.; Sandvik, K.; Selnes, F. Direct and Indirect Effects of Commitment to a Service Employee on the Intention to Stay. J. Serv. Res. 2003, 5, 356-368. [CrossRef]

31. Perry-Smith, J.E.; Shalley, C.E. The Social Side of Creativity: A Static and Dynamic Social Network Perspective. Acad. Manag. Rev. 2003, 28, 89-106. [CrossRef]

32. Fombrun, C. Reputation: Realizing Value from the Corporate Image; Harvard Business School Press: Cambridge, UK, 1996.

33. Rindova, V.P.; Williamson, I.O.; Petkova, A.P. Reputation as an Intangible Asset: Reflections on Theory and Methods in Two Empirical Studies of Business School Reputations. J. Manag. 2010, 36, 610-619. [CrossRef]

34. García-Meca, E.; Palacio, C.J. Board composition and firm reputation: The role of business experts, support specialists and community influentials. BRQ Bus. Res. Q. 2018, 21, 111-123. [CrossRef]

35. Bartels, J.; Pruyn, A.; de Jong, M.; Joustra, I. Multiple organizational identification levels and the impact of perceived external prestige and communication climate. J. Organ. Behav. 2007, 28, 173-190. [CrossRef]

36. Smidts, A.; Pruyn, A.T.H.; Van Riel, C.B.M. The Impact of Employee Communication and Perceived External Prestige on Organizational Identification. Acad. Manag. J. 2001, 44, 1051-1062. [CrossRef]

37. Walsh, G.; Mitchell, V.-W.; Jackson, P.R.; Beatty, S.E. Examining the Antecedents and Consequences of Corporate Reputation: A Customer Perspective. Br. J. Manag. 2009, 20, 187-203. [CrossRef]

38. Greening, D.W.; Turban, D.B. Corporate social performance as a competitive advantage in attracting a quality workforce. Bus. Soc. 2000, 39, 254-280. [CrossRef]

39. Lin-Hi, N.; Blumberg, I. The Link between (Not) Practicing CSR and Corporate Reputation: Psychological Foundations and Managerial Implications. J. Bus. Ethics 2016, 1-14. [CrossRef]

40. McWilliams, A.; Siegel, D.S.; Wright, P.M. Corporate Social Responsibility: Strategic Implications. J. Manag. Stud. 2006, 43, 1-18. [CrossRef]

41. Arikan, E.; Kantur, D.; Maden, C.; Telci, E.E. Investigating the mediating role of corporate reputation on the relationship between corporate social responsibility and multiple stakeholder outcomes. Qual. Quant. 2016, 50, 129-149. [CrossRef]

42. Tracy, J.L.; Robins, R.W. Emerging Insights into the Nature and Function of Pride. Curr. Dir. Psychol. Sci. 2007, 16, 147-150. [CrossRef]

43. Jones, D.A. Does serving the community also serve the company? Using organizational identification and social exchange theories to understand employee responses to a volunteerism programme. J. Occup. Organ. Psychol. 2010, 83, 857-878. [CrossRef]

44. Jones, D.A.; Willness, C.R.; Madey, S. Why Are Job Seekers Attracted by Corporate Social Performance? Experimental and Field Tests of Three Signal-Based Mechanisms. Acad. Manag. J. 2014, 57, 383-404. [CrossRef]

45. Ellemers, N.; Kingma, L. Corporate social responsibility as a source of organizational morality, employee commitment and satisfaction. J. Organ. Moral Psychol. 2011, 1, 97-127.

46. De Roeck, K.; El Akremi, A.; Swaen, V. Consistency Matters! How and When Does Corporate Social Responsibility Affect Employees' Organizational Identification? J. Manag. Stud. 2016, 53, 1141-1168. [CrossRef]

47. Turner, M.R.; McIntosh, T.; Reid, S.W.; Buckley, M.R. Corporate implementation of socially controversial CSR initiatives: Implications for human resource management. Hum. Resour. Manag. Rev. 2018. [CrossRef]

48. Choi, Y.; Yu, Y. The Influence of Perceived Corporate Sustainability Practices on Employees and Organizational Performance. Sustainability 2014, 6, 348-364. [CrossRef]

49. Tyler, T.R.; Blader, S.L. Autonomous vs. comparative status: Must we be better than others to feel good about ourselves? Organ. Behav. Hum. Decis. Process. 2002, 89, 813-838. [CrossRef]

50. Behrend, T.S.; Baker, B.A.; Thompson, L.F. Effects of Pro-Environmental Recruiting Messages: The Role of Organizational Reputation. J. Bus. Psychol. 2009, 24, 341-350. [CrossRef]

51. Tett, R.P.; Meyer, J.P. Job satisfaction, organizational commitment, turnover intention, and turnover: Path analyses based on meta-analytic findings. Pers. Psychol. 1993, 46, 259-293. [CrossRef]

52. Ghapanchi, A.H.; Aurum, A. Antecedents to IT personnel's intentions to leave: A systematic literature review. J. Syst. Softw. 2011, 84, 238-249. [CrossRef]

53. Long, C.; Azami, A. An Analysis on the Relationship between Work Family Conflict and Turnover Intention: A Case Study in a Manufacturing Company in Malaysia. Int. Bus. Manag. 2016, 10, 176-182.

54. Dutton, J.; Dukerich, J.; Harquail, C. Organizational images and member identification. Adm. Sci. Q. 1994, 39, 239-263. [CrossRef]

55. Gouthier, M.H.J.; Rhein, M. Organizational pride and its positive effects on employee behavior. J. Serv. Manag. 2011, 22, 633-649. [CrossRef]

56. Hacker-Wright, J. Moral Status in Virtue Ethics. Philosophy 2007, 82, 449-473. [CrossRef]

57. Drydyk, J. A Capability Approach to Justice as a Virtue. Ethical Theory Moral Pract. 2012, 15, 23-38. [CrossRef]

58. Roberts, R.C. Justice as an Emotion Disposition. Emot. Rev. 2010, 2, 36-43. [CrossRef]

59. Colquitt, J. On the dimensionality of organizational justice: A construct validation of a measure. J. Appl. Psychol. 2001, 86, 386-400. [CrossRef] [PubMed]

60. Colquitt, J.A.; Conlon, D.E.; Wesson, M.J.; Porter, C.O.L.H.; Ng, K.Y. Justice at the millennium: A meta-analytic review of 25 years of organizational justice research. J. Appl. Psychol. 2001, 86, 425-445. [CrossRef]

61. Colquitt, J.; Scott, B.; Rodell, J.; Long, D.; Zapata, C.; Conlon, D.; Wesson, M. Justice at the millennium, a decade later: A metaanalytic test of social exchange and affect-based perspectives. J. Appl. Psychol. 2013, 98, 199-236. [CrossRef] 
62. Haynie, J.J.; Mossholder, K.W.; Harris, S.G. Justice and job engagement: The role of senior management trust. J. Organ. Behav. 2016, 37, 889-910. [CrossRef]

63. Flaherty, K.E.; Pappas, J.M. The Role of Trust in Salesperson-Sales Manager Relationships. J. Pers. Sell. Sales Manag. 2000, 20, 271-278. [CrossRef]

64. Lilly, J. The Impact of Justice Type on Organizational Citizenship Behavior: Do Outcome Favorability and Leader Behavior Matter? Curr. Psychol. 2015, 34, 26-49. [CrossRef]

65. Rupp, D.E.; Shao, R.; Thornton, M.A.; Skarlicki, D.P. Applicants' and Employees' Reactions to Corporate Social Responsibility: The Moderating Effects of First-Party Justice Perceptions and Moral Identity. Pers. Psychol. 2013, 66, 895-933. [CrossRef]

66. Holtz, B.C.; Harold, C.M. Interpersonal Justice and Deviance. J. Manag. 2013, 39, 339-365. [CrossRef]

67. Edwards, M.R.; Kudret, S. Multi-foci CSR perceptions, procedural justice and in-role employee performance: The mediating role of commitment and pride. Hum. Resour. Manag. J. 2017, 27, 169-188. [CrossRef]

68. Ko, S.H.; Moon, T.W.; Hur, W.M. Bridging Service Employees' Perceptions of CSR and Organizational Citizenship Behavior: The Moderated Mediation Effects of Personal Traits. Curr. Psychol. 2018, 37, 816-831. [CrossRef]

69. Shin, I.; Hur, W.; Kang, S. Employees' Perceptions of Corporate Social Responsibility and Job Performance: A Sequential Mediation Model. Sustainability 2016, 8, 493-505. [CrossRef]

70. Brislin, R.W. The wording and translation of research instruments. In Field Methods in Cross-Cultural Research; Lonner, W.J., Berry, J.W., Eds.; Sage: Beverly Hills, CA, USA, 1986; pp. 137-164.

71. Turker, D. Measuring corporate social responsibility: A scale development study. J. Bus. Ethics 2009, 85, 411-427. [CrossRef]

72. Ahearne, M.; Mathieu, J.; Rapp, A. To empower or not to empower your sales force? An empirical examination of the influence of leadership empowerment behavior on customer satisfaction and performance. J. Appl. Psychol. 2005, 90, 945-955. [CrossRef] [PubMed]

73. Fournier, C.; Tanner, J.F.; Chonko, L.B.; Manolis, C. The Moderating Role of Ethical Climate on Salesperson Propensity to Leave. J. Pers. Sell. Sales Manag. 2010, 30, 7-22. [CrossRef]

74. Hair, J.F.; Anderson, R.E.; Babin, B.J.; Black, W.C. Multivariate Data Analysis: A Global Perspective; Pearson: Upper Sadd, NJ, USA, 2010.

75. Fornell, C.; Larcker, D.F. Evaluating Structural Equation Models with Unobservable Variables and Measurement Error. J. Mark. Res. 1981, 18, 39-50. [CrossRef]

76. Podsakoff, P.M.; MacKenzie, S.B.; Podsakoff, N.P. Sources of Method Bias in Social Science Research and Recommendations on How to Control It. Annu. Rev. Psychol. 2012, 63, 539-569. [CrossRef]

77. Podsakoff, P.M.; MacKenzie, S.B.; Lee, J.-Y.; Podsakoff, N.P. Common method biases in behavioral research: A critical review of the literature and recommended remedies. J. Appl. Psychol. 2003, 88, 879-903. [CrossRef]

78. Hayes, A.F. Introduction to Mediation, Moderation, and Conditional Process Analysis: A Regression-Based Approach; Guilford Publications: New York, NY, USA, 2013; ISBN 1609182308.

79. Malhotra, M.K.; Singhal, C.; Shang, G.; Ployhart, R.E. A critical evaluation of alternative methods and paradigms for conducting mediation analysis in operations management research. J. Oper. Manag. 2014, 32, 127-137. [CrossRef]

80. Dawson, J.F. Moderation in Management Research: What, Why, When, and How. J. Bus. Psychol. 2014, 29, 1-19. [CrossRef]

81. Deutsch, M. Equity, Equality, and Need: What Determines Which Value Will Be Used as the Basis of Distributive Justice? J. Soc. Issues 1975, 31, 137-149. [CrossRef]

82. Skarlicki, D.P.; Kulik, C.T. Third-party reactions to employee (MIS)treatment: A justice perspective. Res. Organ. Behav. 2004, 26, 183-229. [CrossRef]

83. Chong, M. Employee Participation in CSR and Corporate Identity: Insights from a Disaster-Response Program in the Asia-Pacific. Corp. Reput. Rev. 2009, 12, 106-119. [CrossRef]

84. Lock, I.; Seele, P. Theorizing stakeholders of sustainability in the digital age. Sustain. Sci. 2017, 12, 235-245. [CrossRef]

85. Bobko, P.; Stone-Romero, E.F. Meta-analysis may be another useful tool, but it is not a panacea. In Research in Personnel and Human Resources Management; Elsevier Science/JAI Press: Greenwich, CT, USA, 1998; pp. 359-397. ISBN 0762303689.

86. del Mar Alonso-Almeida, M.; Perramon, J.; Bagur, L. Women managers and corporate social responsibility (CSR) in Spain: Perceptions and drivers. Womens Stud. Int. Forum 2015, 50, 47-56. [CrossRef]

87. Díaz Chica, O.; Tapia Frade, A.; De Diego Vallejo, R. Does a socially responsible prototypical leader exist in Spain? Cuad. Gest. 2019, 19, 53-84. [CrossRef]

88. Feng, C.; Fay, S.; Xiang, K. When do we need higher educated salespeople? The role of work experience. Rev. Manag. Sci. 2020, 1-39. [CrossRef] 